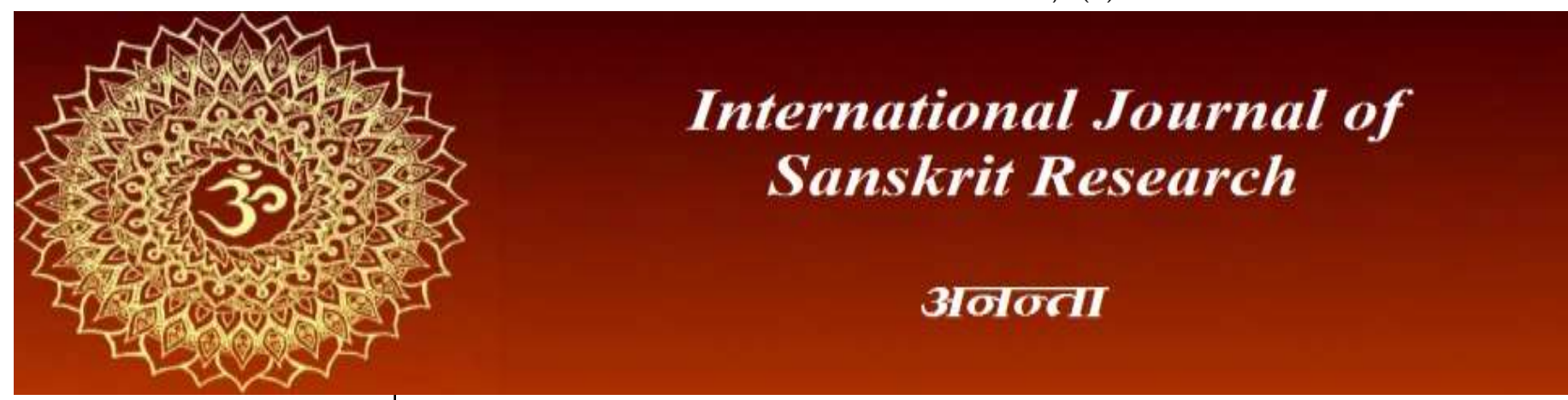

ISSN: 2394-7519

IJSR 2021; 7(5): 258-260

(C) 2021 IJSR

www.anantaajournal.com

Received: 18-07-2021

Accepted: 09-08-2021

Ramakrishna Pejathaya Associate Professor,

Department of Linguistics and

Literary Studies, Chinmaya

Vishwavidyapeeth, Ernakulam,

Kerala, India

Anagha Pradeep

MA Sanskrit Studies, 3rd

Semester, University of

Hyderabad, Telangana, India
Corresponding Author: Ramakrishna Pejathaya Associate Professor,

Department of Linguistics and Literary Studies, Chinmaya Vishwavidyapeeth, Ernakulam, Kerala, India

\section{Sahrdaya: A touchstone for creative imagination}

\section{Ramakrishna Pejathaya and Anagha Pradeep}

DOI: https://doi.org/10.22271/23947519.2021.v7.i5e.1511

\section{Abstract:}

The success or fruitfulness of any art depends upon both the artist and the connoisseur. In fact, it is the connoisseurs because of whom a poetry or an art excels and remains forever. Sahṛdaya, sāmājika, saceta, bhāvaka and rasika are some major terms that have been used for a connoisseur in Sanskrit (poetics or aesthetics) works. It is noteworthy that Indian aesthetics has identified such significance of the connoisseurs and tried to define him.

This paper discusses how Indian poetics explains the attributes a connoisseur should have to appreciate any art, with an emphasis on the beauty of the terms sahṛdaya and bhāvaka.

Keyword: Connoisseur, Sanskrit, literature, poetics, aesthetics, poetry

\section{Introduction}

The three important aspects in the world of art ${ }^{[1]}$ are the artist ${ }^{[2]}$, the connoisseur and the work of the artist (literary or performing). In fact, the work of the artist is the soul of any art. The success or fruitfulness of any art depends upon both the artist and the connoisseur. This is because art is a samvāda (communication) between the artist and connoisseur, initiated by the former. Since the performance of an artist is very important for the excellence of any art, there have been many texts which describe the qualities that an artist must hold and the training he must undergo. However, Indian aesthetics also emphasises the attributes that a connoisseur must possess in order to appreciate the nuances of art. The effort of an artist attains its object or becomes fruitful only when the artist has performed it to the best of his ability and the connoisseur has appreciated and enjoyed it duly. This article discusses how Indian poetics explains the attributes a connoisseur should have to appreciate any art, with an emphasis on the beauty of the terms sahrdaya and bhāvaka.

\section{Who is a Sahrdaya?}

Some major terms used for a connoisseur in Sanskrit (poetics or aesthetics) works are sahṛdaya, sāmājika, saceta, bhāvaka and rasika. The term sāmājika was first used by Bharatamuni in his Nātyaasāstra, followed by other ancient scholars, while the term sahṛdaya has been employed by poeticians such as Ānandavardhana. Rājaśekhara in his celebrated work Kāvyamīmāṃsā has coined the term bhāvaka and he even classifies the bhāvakas in four categories.

In our view, sahrdaya is the most beautiful term amongst all. Literary sahrdaya means the one who has a heart like that of the poet: samānam hṛdayam yasya sạ̣ sahṛdayah.

Abhinavagupta further defines the sahṛdaya as:

“yeșāim kā vyānuśìlanābhyāsavaśād-viśadībhūte manomukure varnanīya-tanmayībhavanayogyatā te hrdaya-samivāda-bhājah sahrdayāḥ"

Sahrdayas are the ones whose minds' mirrors, cleansed by involved appreciation and dedicated practice of poetry, are capable of wholly immersing themselves in the described, and whose hearts feel the same way as the poet's did while penning the verse, and whose hearts silently comprehend even the poet's unspoken thoughts ${ }^{[3,4]}$.

In order to understand this term better, let us see an example. A dancer while trying to portray anger in his performance, depicts it with enlarged eyes, raised eyebrows, teeth stuck together and so on. To indicate the bank of a river the dancer uses 'ardhapatākā' hasta. 
These actions of the dancer have to be understood by the connoisseur, else it makes no sense. To comprehend this the connoisseur must have a mind that aligns to the thoughts of the dancer. The same applies to poetry or other literary works as well. The poet/author uses indirect expressions to evoke rasa in the connoisseur through suggestive power. This may be done with tools such as alankāras (figures of speech) and gunas. It is required that the reader must also have some knowledge of these for him to enjoy the poem or other literary works. It is only when the connoisseur orients himself to the artist that he enjoys the work of the artist to his fullest, attaining paramānanda. We are all quite familiar with the concept of rasa. The one who experiences the rasa is called a rasika. However, to be a rasika, it is required that the person should be a sahrdaya first. This is the reason the word sahrdaya has been coined thus, giving us this beautiful meaning.

The presentation of the artist and the experience of a connoisseur are the two major pillars of this mansion called art. There are many prayojanas (objects) of an art, such as purușārtha-prāpti, vyavahāra-jñāna, kāntā-sammitatayā upadeśa, sadyah-paranirvṛti and so on mentioned in the poetic works. Sahrdayatva is an important attribute for people to attain these objects together or individually. Thus, we understand the importance of the role of a sahrdaya when seen through various perspectives.

The one who understands these facts really enjoys and appreciates the statement of Abhinava-gupta at the beginning of his Locana commentary of Dhvanyāloka:

\section{"sarasvatyāstattvaí kavisahrdayākhyam vijayate"}

The tattva of Goddess Sarasvati named kavisahrdaya only excels" ${ }^{[5]}$.

Interestingly, the work Dhvanyāloka had some other names also. Noteworthy amongst those are Sahṛdayahṛdayāloka and Sahrdayāloka. These names clearly communicate that the work was majorly written from a sahrdaya's point of view and it helps him to understand and appreciate poetry (and art).

\section{Bhāvaka: As Defined by Rājaśekhara}

Rājaśekhara in his Kāvyamīmāmsa, while describing kāvyahetu (cause of poetry), mentions that the artist possesses kārayitrī pratibhā and the connoisseur possesses bhāvayitrī pratibhā ${ }^{[6]}$. This is how he explains bhāvayitrī pratibhā:

\section{bhāvakasyopakurvāṇā bhāvayitrī. sā hi kaveh śramamabhiprāyaìca bhāvayati. tayā khalu phalitặ kavervyāpārataruh. anyathā so 'vakeśī syāt.}

That which helps a bhāvaka ${ }^{[7]}$ is called a bhāvayitri. This helps in understanding the effort and opinion of the artist. Only then does the tree of the artist's work fructify. Else, it becomes barren ${ }^{[8]}$. This clearly states that the effort of an artist becomes useless without a sahridaya. Again, note that the connoisseur or bhāvaka is also considered to possess pratibhā (creativity). It is evident that an artist must possess pratibhā. But many people may wonder why that should be the case for a sahrdaya also. Here is the answer. When the artist conveys a message (without expressly stating it), the sahrdaya must be able to understand and connect to it. For this, it is required that the sahrdaya too must have some knowledge and creativity.

However, Rājaśekhara makes a clear distinction between the two, stating that in the case of an artist it is the pratibhā which creates and when it comes to the sahrdaya, the bhāvaka it is which appreciates.

Rājaśekhara also mentions that there are four types of bhāvakas ${ }^{[9]}$. They are:

- Arocak $\overline{1}$ - the one who truly enjoys the art to their fullest;

- Satṛnābhyavahārī - the one who enjoys everything and is pleased with any sort of performance;

- Matsarī - the one who can enjoy the art but tries to find fault with the artist's work;

- Tattvābhiniveśi - the one who spectates the art with predetermined theories and who is unable to accept the artist's creativity no matter how beautifully the work is presented.

Among them arocakī is the best, opines Rājaśekhara. He further elaborates the idea through a conversational poem:

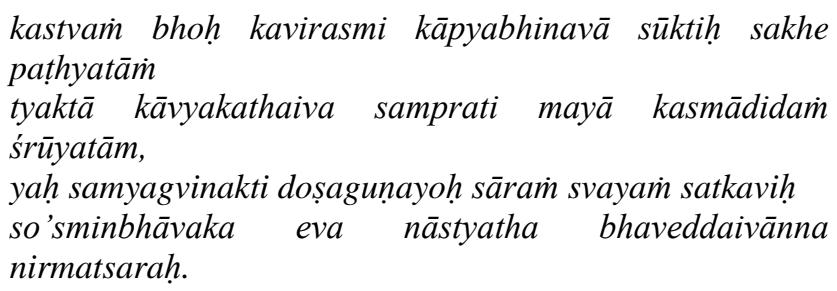

Who are you?

I am a poet.

Dear friend! Then please recite any new composition.

I have given up that topic (composing poems) itself.

Why so?

Listen to me. [He] who can analyse the merits and blemishes (and can appreciate the poetry) and himself [be] a good poet, such a bhāvaka is not there. Although such person is found with god's grace, there are minimal chances that that person is not jealous ${ }^{[10]}$.

\section{Conclusion}

All these discussions beautifully describe how sahrdayatva is important for the existence and excellence of any art form. Just as a jīvanmukta is the ultimate pramāṇa in Advaita philosophy or śisța is the ultimate pramāṇa in vyākaraṇa, sahridaya is the ultimate pramāna in any art. This has been stated very well by Kalidasa in his Raghuvamśa where he ascertains and compares the sahrdayas to the fire and his work to the gold: hemnaḥ samilakṣyate hyagnau viśuddhiśśyāmikāpi $v \bar{a}-$ It is the fire that determines the purity of the gold ${ }^{[11]}$.

Here is a verse of Vijjhika, a celebrated poet of the 8th century and the daughter-in-law of Immadi Pulakeshi, to conclude with. This verse nicely presents what happens when both kavi and sahrdaya at the top in their roles. She says:

\section{kaver-abhiprāyam-aśabdagocaram sphurantam-ārdreșu padeșu kevalam, vadadbhir-angaih krta-roma-vikriyaih janasya tūṣnīm bhavato 'yamañjalih.}

This is a homage with folded hands to you who are silent, (but) who by his horripillated limbs indicates the ideas of the poet that are inexpressible by words, (but) flash forth only through words fraught with tender feelings ${ }^{[12]}$.

Both the intention of the poet and the appreciation of the sahrdaya have not been stated explicitly. But there was a beautiful communication between them which led both into rasānanda. 


\section{References}

1. Both literary and performing arts.

2. Poet, author, musician, dancer, actor etc.

3. Dhvanyāloka of Anandavardhana With Locana. Varanasi: Motilal Banarasidas, 2011, p23.

4. Translation courtesy: Mrs. Neethu S. Kumar, CVV, Ernakulam.

5. Dhvanyāloka (with locana) p1.

6. According to Apte, pratibhā refers to bright complexion or vivid imagination.

7. भावयतीति भावक: - the one who experiences is called bhāvaka.

8. Ramaswami Shastri Shiromani KS. Kāvyamīmāṃsa of Rajashekhara. Baroda: Oriental Institute. Retrieved from archive.org. Chapter 4, 1934, p13.

9. Kāvyamīmāṃsa, Chapter 4, p13.

10. Ibid., p14.

11. M. R. Kale. Raghuvamśa of Kalidasa. Varanasi: Motilal Banarasidas.1.10.

12. Sharma KV. Mahāsubhāṣitasangraha. Hoshiarpur: Vishweshwaranand Vedic Research Centre. Retrieved from archive.org. 1981;V:2363. 